\title{
Influence of different commercial yeasts on the phenol pattern of rosé wine
}

\author{
Karin Mandl ${ }^{\mathrm{a}}$, Karin Silhavy-Richter, Silvia Wendelin, Martin Prinz, Elsa Patzl-Fischerleitner, and Reinhard Eder \\ Federal College and Research Center of Pomology and Viticulture
}

\begin{abstract}
In this experiment, 27 different commercial yeasts were tested for their influence on the phenols of a rosé wine. The phenols depend primarily on the vine variety, cultivation and cellar processing. This experiment sought to clarify how great the influence of the yeast on the phenols is. Blaufränkisch grapes with $20^{\circ} \mathrm{KMW}$ were matured in the cellar with 27 different commercial yeasts. The vinification was carried out in 341 vessels. An HPLC Agilent Technology 1220 (RRLC) with a column of ZORBAX SB-C18 $15 \times 2.1 \mathrm{~mm}(1.8 \mu \mathrm{m})$ was used for the measurement. $5 \mu \mathrm{l}$ of the sample were injected directly. The column oven temperature was $40{ }^{\circ} \mathrm{C}$. The transient was $0.5 \%$ formic acid $(\mathrm{pH}=2.3)$ and a gradient of methanol $(3 \%$, $4 \%, 14 \%, 30 \%$ and $70 \%$ ). The detection took place at 280 and $320 \mathrm{~nm}$. It was shown that the effect of yeast on phenols is low. There was a great influence on the chemical substance tyrosol. This is a phenol that can be formed by the yeast itself. The values varied between $5.4 \mathrm{mg}$ and $13.2 \mathrm{mg} / \mathrm{l}$. The already described influence of the duration of fermentation on tyrosol formation could not be confirmed.
\end{abstract}

\section{Introduction}

In this experiment with rosé wine, 27 different commercial yeasts were examined for the influence of phenols in the same starting must. The question arises if differences in the phenol pattern result from the influence of the yeast.

In principle, phenols can be subdivided into flavonoids, phenolic carboxylic acids, volatile phenols, stilbenes, polymeric phenols, and condensed and hydrolyzable tannins. More than 800 different substances have already been described [3] Their effect is mainly in the defense of the plant, in attracting animals by means of colorants and odorants to spread the seeds and as a free radical scavenger $[1,4,8]$. The phenols of the wine have a great effect on human health. The positive effects of the "French paradox" are well known [6].

\section{Material and methods}

Must: Grapes from the Blaufränkisch variety from the vineyard Götzhof, Langenzersdorf were used for the production of trial wine. The must had a gradation of $20^{\circ} \mathrm{KMW}$, a total acid of $5.1 \mathrm{~g} / \mathrm{l}$. The fermentation was carried out in 341 glass containers in the cellar department.

27 yeast: Uvaferm WAM, Filtraferm C, Lalvin Opal ICV, Zymaflore Alpha X5, Siha Rubin Cru, Zymaflore X5, Prezisio Red \& Fruity, Prezisio Arom C, Fermicru AR2, Littolevure Pink, Siha Active Yeast 3, Oenoferm Freddo, Filtraferm Extract, Filtraferm C Fresh, Lalvin EC 1118, Oenoferm Pino Type, Lalvin Rhone 2056, Siha Active Yeast 8, Actiflore Rosé, Preziso White \& Fruity, Oenoferm Rosé, Fermicru Rosé, Fermiflor, Lalvin Rhone 4600, Oenoferm Rouge, Oenoferm Tipico, Oenoferm Klosterneuburg Phenol Analysis: An HPLC

a e-mail: Karin.Mandl@weinobst .at
Agilent Technology 1220 (RRLC) with a column of ZORBAX SB-C18 $15 \times 2.1 \mathrm{~mm}(1.8 \mu \mathrm{m})$ was used. $5 \mu \mathrm{l}$ of the sample were injected directly. The column oven temperature was $40^{\circ} \mathrm{C}$. The transient was $0.5 \%$ formic acid $(\mathrm{pH}=2.3)$ and a gradient of methanol $(3 \%, 4 \%$, $14 \%, 30 \%$ and $70 \%)$. The detection took place at 280 and $320 \mathrm{~nm}$.

\section{Results and discussion}

Gallic acid, a tannin which naturally occurs in plants and/or can be formed from tannins, was in a range of $0.6 \mathrm{mg} / \mathrm{l} \pm 0.2 \mathrm{mg}$. The measurements also fluctuated within this range during the repetitions. In grapes, gallic acid, a 3,4,5-trihydroxybenzoic acid, is present only to a small extent, and it is very susceptible to oxidation and tastes generally tart and sour. In the industry, this substance is often used as an antioxidant for cosmetics and foodstuffs. "The alkyl esters of gallic acid, besides their anti-oxidative action, have a microbicidal effect against Saccharomyces cerevisiae. It increases with increasing chain length of the alkyl radical, that is, with increasing fat solubility of the esters. The effect of gallates on yeast first manifests itself in a clear fermentation inhibition. This inhibition is not specific. The metabolism of the yeast is also impaired in a different way. For example, under the influence of fermentation-inhibiting gallate concentrations, the cells formed were always smaller than without gallate. Under certain conditions, however, increased numbers of cells were found in gallate-containing fermentations. Fermentation inhibition by gallic acid esters ultimately results from the death of the yeast cells. The yeast cell absorbs gallate until a lethal concentration is reached, which leads to cell death. Since this material intake is relatively slow, yeast can even multiply under the influence of fermentation-inhibiting

(C) The Authors, published by EDP Sciences. This is an Open Access article distributed under the terms of the Creative Commons Attribution License 4.0 (http://creativecommons.org/licenses/by/4.0/). 
- Tyrosol $\quad$ feremtation days

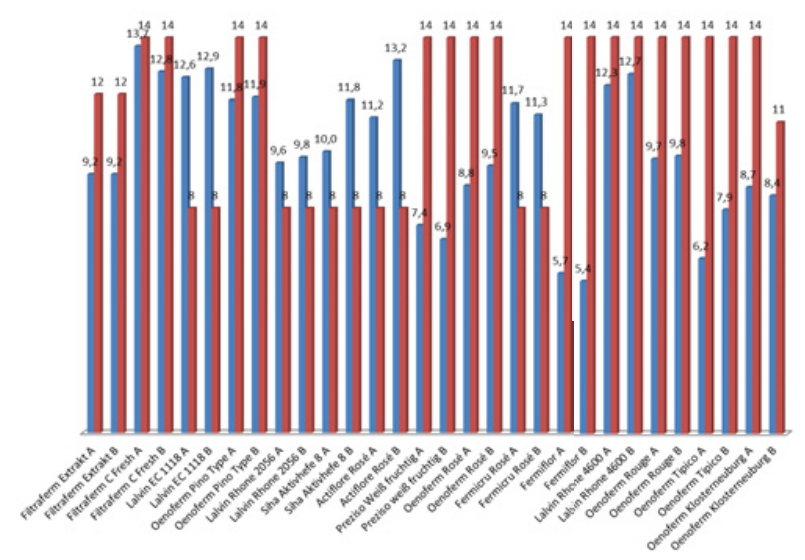

Figure 1. Illustration of the different tyrosol values depending on the fermentation time.

\section{- Tyrosol = fermentation days}

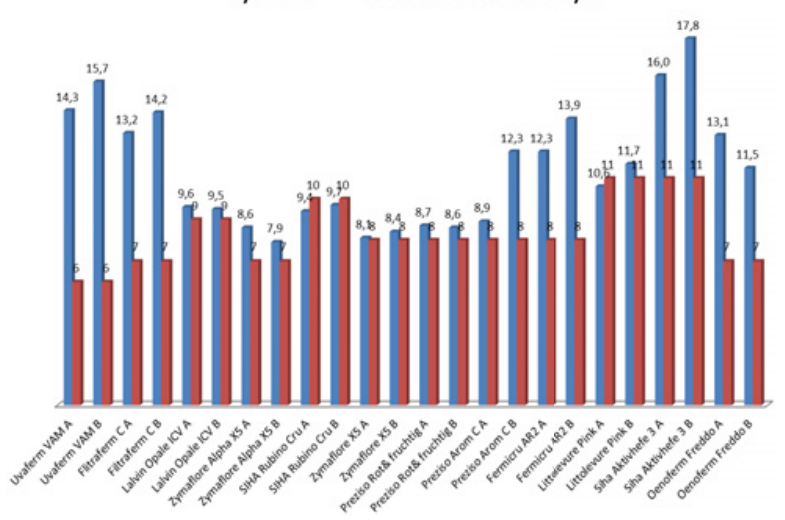

Figure 2. Illustration of the different tyrosol values depending on the fermentation period.

gallate concentrations. The short yeast production time prevents the accumulation of a lethal gallate concentration in the cell. This lethal, intracellular gallate concentration can only arise when the stationary cell number is reached. In optimal substrates, which allow the yeast to grow quickly, the fermentation-inhibiting concentrations of gallate are not sufficient to suppress growth since they are too slow. Only the cell mass already formed is subsequently killed. The killing effect of the gallic acid esters is probably due to the denaturation of cell protein, since the yeast cells become smaller under the action of gallate" [2].

Caftaric acid, a hydroxycinnamic acid derivative, was found in a range of fluctuation of $50 \mathrm{mg} / \mathrm{l} \pm 4 \mathrm{mg}$. The samples showed no association with inoculation with the yeast.

Tyrosol has a strong antioxidant effect and offers cell protection. The phenol is the only chemical substance produced during fermentation by the yeast $[5,9]$ and the results of the experiment show a strong connection with the yeast. Fermentation without oxygen forms more tyrosol than with oxygen [10]. It was shown in Figs. 1 and 2 that there is no influence on fermentation time. The values in this yeast experiment vary from $5.4 \mathrm{mg} / \mathrm{l}$ to $13.2 \mathrm{mg} / \mathrm{l}$ and the values of the individual repetitions are very close together.

Trans-coutaric acid is the main derivative of hydroxycinnamic acid in the berry skin. This component serves as a vehicle for anthocyanins. The values of trans-coutaric acid and cis-coutaric acid are very close together.

Procyanidine B1 (epicatechin $(4 \beta \rightarrow 8)$ catechol) and procyanidine B2 $(-)$ - epicatechin $(4 \beta \rightarrow 8)$ $(-)$ - epicatechin belong to the flavonoids. The different commercial yeasts showed no difference in behavior.

Coffee acid, 3,4-dihydroxycinnamic acid belongs to the group of hydroxycinnamic acids and phenolic acids. Coffee acid is one of the most common secondary plant products. In our experiment, values of $2.3 \mathrm{mg} / \mathrm{l} \pm 0.3 \mathrm{mg} / \mathrm{l}$ were determined.

Fertaric acid occurs in grapes as well as in wine. This acid is readily esterified with tartaric acid, and in our experiment fertaric acid showed a fluctuation of $2.1 \mathrm{mg} / \mathrm{l} \pm 0.2 \mathrm{mg} / \mathrm{l}$ for all yeasts.

Para-coumaric acid belongs to the hydroxycinnamic acids, which are often found in the presence of vine. The contents depend on the type and maturity of the material. $0.9 \mathrm{mg} / \mathrm{l} \pm 0.3 \mathrm{mg}$ were determined. There is an influence shown by the yeast.

P-coumaric acid is the precursor for 4-ethylphenol, which is formed by the Brettanomyces yeasts (Šucur et al. 2016) in wine. 4-vinylphenol is converted by means of the enzyme cinnamate decarboxylase. 4-vinyphenol is further reduced to 4-ethylphenol by means of the enzyme vinyphenol reductase. This specific reaction for Brettanomyces is often replicated in selection media. Coumaric acid is often added to microbiological media to identify Brettanomyces by the smell.

Epicatechin: the values are at $2.3 \mathrm{mg} / \mathrm{ml} \pm 1 \mathrm{mg} / \mathrm{ml}$. The numbers for the comparable yeasts fluctuate very strongly and this suggests that the influence of the yeast is low here. Epicatechin gallate is a flavanol, a typical polyphenol. Polyphenols are secondary plant metabolites and constituents of the vine and of the wine and thus influence the sensory characteristics of the wine. The yeast affects the polyphenols mainly by the ability to absorb substances through the cell wall.

Ferulic acid belongs to the hydroxycinnamic acids and is often esterified with tartaric acid. It serves as a precursor for 4-ethylguaiacol, an off-aroma formed by Brettanomyces [11]. The influence of the yeast on the material is apparent. The data of the repeats are parallel and in a range of $0.8 \mathrm{mg} / \mathrm{l} \pm 0.3 \mathrm{mg} / \mathrm{l}$.

\section{References}

[1] S. Cesco, T. Mimmo, G. Tonon, N. Tomasi, R. Pinton, R. Teranzo, G. Neumann, L. Weisskopf, G. Renella, L. Lamdi, P. Nannipieri, Biol. Fertil Soils 48, 123 149 (2012)

[2] H.H. Dittrich, E. Kerner, Wein-Wissen. 19, 528-535 (1966)

[3] R. Eder, S. Wendelin, ALVA Tagungsband, 293-296 (2002)

[4] S. Hassan, U. Mathesius, Journal of Experimental Botany 63(9), 3429-3444 (2012) 
[5] L.A. Hazelwood, J.M. Daran, A.J. von Maris, J.T. Pronk, J.R. Dickson, Appl. Environ Microbiol 74, 2259-2266 (2008)

[6] B. Kleine-Gunk, Reservatrol, Länger jung mit der Rotwein-Medizin: Reservatrol verlängert die Lebenszeit und schützt nachweislich vor Krankheiten, Trias Verlag (2009)

[7] H. König, G. Unden, J. Fröhlich, Biology of microorganisms on grapes, in must and in wine, Springer Verlag, 307-334 (2008)
[8] W.A. Müller, S. Frings, F. Möhrlen, Tier- und Humanphysiologie, eine Einführung, 5. Auflage Springer Spektrum Verlag (2015)

[9] Z. Pineiro, E. Cantos-Villar, M. Palma, B. Puertas, J. Agri. Food Chem. 56, 11683-11689 (2011)

[10] Y. Romboli, S. Mangani, G. Buscioni, L. Granchi, M. Vincenzini, Journal of Microbiology and Biotechnology 31(7), 1137-1145 (2015)

[11] S. Šucur, N. Čadez, T. Kosmerl, Acta agriculturae Slovenica 107(2), 453-472 (2016) 